\title{
ИЗУЧЕНИЕ СВОЙСТВ АНТИ-АМИЛОИДНОГО АГЕНТА АМИЛОВИС НА ТРАНСГЕННОЙ ЖИВОТНОЙ МОДЕЛИ БОЛЕЗНИ АЛЬЦГЕЙМЕРА
}

\author{
В.О. Небогатиков ${ }^{1,2}$, Е.А. Вихарева ${ }^{2}$, А.А. Устюгов ${ }^{1,2}$, Р. Менендес ${ }^{3}$, \\ В.А. Митькевич ${ }^{4}$, Г.В. Малеев ${ }^{1,2}$ \\ ${ }^{1} 000$ «БиоНейроФарма», 143026, Российская Федерация, г. Москва, территория \\ Сколковоинновационного центра, Большой бульвар, д. 42, стр. 1. \\ ${ }^{2}$ ИФАВ РАН, 14232, Российская федерация, г. Черноголовка, Северный проезд, 1. \\ ${ }^{3}$ DepartmentofNeurochemistry, CubanNeuroscienceCenter, \\ Cuba, LaHabana, CubanacánPlaya, Ave 25 No. 15202, Esq. 158. \\ 4ИМБ РАН, 119991, Российская Федерация, г. Москва, ул. Вавилова, д. 32.
}

DOI: 10.19163/MedChemRussia2021-2021-64

E-mail:vnebogatikov@gmail.com

Нами были исследованы свойства новых соединений из ряда Амиловис на основе биологически активных производных нафталинана трансгенной животной модели церебрального амилоидоза (линия 5XFAD). Ранее в тестах in vitro, e xvivo и in silico было отмечено свойство соединения эффективно замедлять агрегацию белков [1]. Также были получены данные о безопасности соединения. Используя методы глобального fullblind докинга и локального докинга, мы подтвердили высокую степень связывания соединения Амиловис с сайтами A $\beta 7-23$ и А $355-40$. Эффективность связывания Амиловис с данными сайтами подтверждается проведённым калориметрическим исследованием. Показано, что константа диссоциации отличается, например, от таковой для сайта Аß30-40 более, чем в 3 раза. Были изучены эффекты хронического введения соединения на моторные и когнитивные функции мышей линии 5xFAD, в сравнении с диким типом C57BI6. В 10 месячном возрасте у животных был проведён гистохимический анализ количества амилоидных агрегатов в коре головного мозга и гиппокампе. Использованные методы оценки когнитивной функции животных (водный лабиринт Морриса, тест «Узнавание нового объекта») не выявили достоверных различий между дикотипными и трансгенными животными. Поведение в тесте «Открытое поле» и некоторые показатели моторной функции трансгенных животных отличались от контрольных, но при введении соединения Амиловисзначения этих параметров были ближе к контрольным. Гистохимический анализ тканей животных показал, что введение соединения Амиловис значительно сокращает количество амилоидных агрегатов в гиппокампе у мышей $5 x \mathrm{FAD}$.

Данная работа выполнена с использованием оборудования ЦКП ИФАВ РАН.

\section{Литература}

[1] S. Rivera-Marrero, A. Bencomo-Martínez, E. O. Salazar, etal., Bioorganic \& MedicinalChemistry, 2020, V.28, I. 20, 115700. 